\title{
MAQASHID AL-SYARI'AH DAN RELEVANSINYA DALAM KONTEKS KEKINIAN
}

\author{
Ridwan Jamal ${ }^{1}$
}

\begin{abstract}
Abstrak
Salah satu kajian utama bidang ushul fiqh adalah tentang maqashid al-syari'ah, tujuan diturunkannya hukum. Kajian ini terfokus pada kebutuhan pokok yang harus dimiliki oleh manusia. Kebutuhan tersebut yaitu kebutuhan primer, sekunder dan pelengkap, yang oleh Imam al-Ghazali disebut sebagai dharury, hajy dan tahsiny. Maqashid as-syari'ah adalah upaya "terjemahan" kehendak pembuat hukum (Allah) dan realitas kehidupan manusia. Dalam memahami dinamika hukum Islam yang berkaitan dengan maqashid yang mengandung kemaslahatan duniawi dan ukhrawi, secara hakiki kedua aspek itu tidak dapat dipisahkan dalam hukum Islam. Oleh karena itu dengan pemahaman maqashid al-syari'ah maka ijtihad dapat dikembangkan terutama dalam menghadapi berbagai permasalahan baru yang tidak disebutkan dalam nash untuk menjawab terhadap permasalahan hukum yang muncul dalam masyarakat.
\end{abstract}

Kata Kunci : Maqashid, Al-Syari'ah

\section{Pendahuluan}

Penilaian dan pemahaman terhadap syariah tentu saja merupakan proses pemikiran dan penalaran manusia, baik dalam bentuk pengenalan terhadap maksud aturan Alquran yang di tunjuk secara jelas maupun dalam bentuk analogi (menganalogkan aturan baru dengan aturan Alquran ). Kedua sifat dan dampak dari keseluruhan proses pemahaman terhadap hukum Tuhan ini yang secara harfiah berarti usaha seseorang dengan mengarahkan daya pikirannya diatur oleh teori hukum.

Dalam proses sejarah aturan-aturan syariah mengalami berbagai ragam interpretasi sehingga melahirkan berbagai konsep. Di antara konsep yang paling masyhur ialah konsep al-Syatibi tentang maqashid al-syaria'ah yang secara literar berarti tujuan penerapan hukum. Sejak terbitnya kitab al-Muwafaqat karya gemilang al-Syatibi, maqashid al-syariah menjadi suatu konsep baku dalam ilmu ushul fiqh yang berorientasi kepada tujuan hukum syariah.

\footnotetext{
${ }^{1}$ Penulis adalah dosen tetap pada Jurusan Syari'ah STAIN Manado
} 
Sebelum al-Syatibi, metode penalaran terhadap nash masih didominasi oleh dua teori, yaitu teori keumuman lafal (umum al-lafz) yang dipegang oleh jumhur ulama dan teori kekhususan sebab (khushush al-sabab) yang dipegang oleh ulama minoritas.

Jumhur ulama menetapkan kaidah bahwa yang menjadi pegangan ialah redaksi lafal umum, bukan sebab khusus (al-ibrah bi umum al-lafaz, la bi khushhush al sabab). Maksud kaidah ini ialah jika suatu nash menggunakan redaksi bersifat umum, maka tidak ada pilihan lain selain menerapkan nash tersebut, sekalipun nash itu turun untuk menanggapi suatu peristiwa khusus.

Sedangkan ulama minoritas menetapkan kaidah bahwa "yang dijadikan pegangan ialah kekhususan sebab, bukan keumuman lafal 'al-ibrah bi khushush al-sabab, la bi umum al-lafdz. Maksudnya ialah jika suatu nash turun untuk menanggapi suatu sebab khusus, atau satu nash mempunyai riwayat sebab nuzul atau sebab wurud, maka yang perlu dipegang ialah sebab khusus tersebut.

Pembicaraan tentang pembentukan atau pengembangan hukum yang dalam istilah ushul fiqh disebut ijtihad berkaitan erat dengan perubahan-perubahan social yang berlangsung dalam kehidupan masyarakat. Secara umum ijtihad ${ }^{2}$ itu dapat dikatakan suatu upaya berpikir secara optimal dalam menggali hukum Islam dari sumbernya untuk memperoleh jawaban terhadap permasalahan hukum yang muncul dalam masyarakat.

Antara upaya ijtihad di satu pihak dan tuntutan perubahan social dipihak lain terhadap suatu interaksi. Ijtihad, baik secara langsung atau pun tidak dipengaruhi oleh perubahan-perubahan social yang diakibatkan oleh antara lain kemajuan ilmu dan teknologi, sedangkan disadari bahwa perubahan-perubahan social itu harus diberi arah oleh hukum, sehingga dapat mewujudkan kebutuhan dan kemaslahatan umat manusia. Dalam tulisan ini penulis membatasi pada bagaimana konsep kemaslahatan dalam maqashid al-syari'ah.

\footnotetext{
${ }^{2}$ Abdul Wahab Khalab, Ilm Ushul al-Fiqh, ( Kairo : Dar Kuwaitiyyah, 1968 ), h. 216
} 


\section{Pengertian}

Sacara lughawi (bahasa) maqashid al-syari'ah terdiri dari dua kata yakni maqashid dan syari'ah. Maqashid adalah bentuk jama' dari maqashid yang berarti المواضع تعدر الي الماء

Yang berarti jalan yang menuju sumber air. Jalan menuju sumber air ini dapat pula dikatakan sebagai jalan kea rah sumber pokok kehidupan. ${ }^{4}$

Sedangkan dalam pengertian istilah menurut Fathi al-Daraini mengatakan bahwa hukum-hukum itu tidaklah dibuat untuk hukum itu sendiri, melainkan dibuat untuk tujuan lain yakni kemaslahatan. ${ }^{5}$ Sedangkan menurut Abu Zahra dalam kaitan ini menegaskan bahwa tujuan hakiki hukum Islam adalah kemaslahatan. ${ }^{6}$ Dan agaknya tidak berlebihan apabila Wael B. Hallaq mengatakan bahwa maqashid al syari'ah adalah upaya mengekspresikan penekanan terhadap hubungan kandungan hukum Tuhan dengan aspirasi hukum yang manusiawi. ${ }^{7}$

Apabila kita teliti arti syari'ah secara bahasa diatas, dapat dikatakan bahwa terdapat keterkaitan kandungan makna antara syari'ah dan air dalam arti keterkaitan antara cara dan tujuan. Sesuatu yang hendak dituju tentu merupakan sesuatu yang amat penting. Syari'ah adalah cara atau jalan. Air adalah sesuatu yang hendak.

Pengaitan syari'ah dengan air dalam arti bahasa ini tanpaknya dimaksudkan untuk memberikan penekanan pentignya syari'ah dalam memperoleh sesuatu yang penting yang disimbulkan. Penyimbulan ini cukup tepat karena air merupakan unsure yang penting dalam kehidupan . urgensi unsure ini ditegaskan oleh firman Allah dalam QS. AlAnbiyah : 30

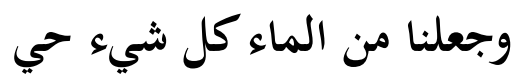

"Dan kami jadikan segala sesuatu dari air “

\footnotetext{
${ }^{3}$ Hans Wehr, A Dectionary of Modern Written Arbic, J. Milton Coan, (ed), ( London : Macdonal and Evans LTD, 1980 ), h. 767

${ }^{4}$ Facthur Rahman, Islam, alih Bahasa Ahsin Muhammad, ( Bandung : Pustaka , 1984 ), h. 140

${ }^{5}$ Fathi al-Daraini, al-Manahij al-usuliyyaah fi Ijtihad bi al-Ra'yi fi al-Tasyri', (Damasyik: Dar alKitab al-Hadis, 1975), h. 28.

${ }^{6}$ Muhammad Abu Zahrah, Ushul al-Fiqh, (Mesir : Dar al-Fikr al-'Arabi, 1958), h. 366.

${ }^{7}$ Wael B. Hallaq, The Frimacy of The Qur'an in Syatibi Legal Theori. Dalam Wael B. Hallaq dan Donald P. Litte (ed) Islamic Studies Presented to Charles J.Adams, (Leiden : EJ-Brill, 1991), h. 89
} 
Pengertian bahasa diatas, menurut penulis agaknya bahwa para ulama memberikan batasan syari'ah dalam arti istilah dengan langsung menyebut tujuan syari'ah itu secara umum. Hal ini terlihat cukup jelas dalam batasan yang dikemukakan oleh Syaitut dan Sayis yang intinya bahwa syari'ah adalah seperangkat hukum-hukum Tuhan yang diberikan kepada umat manusia untuk mendapat kebahagiaan hidup baik di dunia maupun di akhirat. Kandungan pengertian syari'ah yang demikian itu, secara tidak langsung memuat kandungan maqashid al-syari'ah.

Maqashid as-syari'ah secara umum berarti maksud umum ditirunkannya syari'at oleh syari' ( pembuat hukum ).

\section{Pembahasan}

Pembicaraan tentang pembentukan atau pengembangan hukum yang dalam istilah ushul fiqh disebut ijtihad berkaitan erat dengan perubahan-perubahan social yang berlangsung dalam masyarakat. Secara umum ijtihad ${ }^{8}$ itu dapat dikatakan suatu upaya berpikir secara optimal dalam menggali hukum Islam dari sumbernya untuk memperoleh jawaban terhadap permasalahan hukum yang muncul dalam masyarakat.

Anatara upaya ijtihad di satu pihak dan tuntutan perubahan social dipihak lain terdapat suatu interaksi. Ijtihad, baik secara lansung ataupun tidak dipengaruhi oleh perubahan-perubahan social yang diakibatkan oleh antara lain kemajuan ilmu dan teknologi, sedangkan disadari bahwa perubahan-perubahan social itu harus diberi arah oleh hukum, sehingga dapat mewujudkan kebutuhan dan kemaslahatan umat manusia. Menurut Al-Tiwana ijtihad dapat dibagi kepada tiga obyek :

1. Ijtihad dalam rangka memberi penjelasan dan penafsiran terhadap nash

2. Ijtihad dalam melakukan qiyas terhadap hukum-hukum yang telah ada dan telah disepakati.

3. Ijtihad dalam arti penggunaan $r a^{\prime} y u^{9}$

Dalam ilmu sosiologi hukum, hukum dalam posisi di atas dituntut dapat memainkan peran gandah yang sangat penting :

\footnotetext{
${ }^{8}$ Abd al-Wahab Khallaf, 'Ilm Ushul al-Fiqh, (Kairo : Dar Kuwaitiyyah, 1968), h. 216.

${ }^{9}$ Muhammad Musa al-Tiwana, Ijtihad wa Mada Hajatina Ilaih fi Haza al- 'Asr, (T.t, Dar al-Kutub al-Hadisah, t.th), h. 39.
} 
1. Hukum dapat dijadikan sebagai alat control ssosial terhadap perubahanperubahan yang berlangsung dalam kehidupan manusia

2. Hukum dapat dijadikan sebagai alat rekayasa social, ${ }^{10}$ dalam rangka mewujudkan kemaslahatan umat manusia sebagai tujuan hakiki hukum itu sendiri.

Oleh karena itu, pengaturan sebagian masalah social kemasyarakatan adalah dengan nash-nash dalam bentuk pokok-pokoknya saja, maka masalah social kemasyarakatan ini menjadi lapangan ijtihad. Dalam bidang ini, kita dapat melihat dinamika hukum Islam dalam mengantisipasi perkembangan dan perubahan yang terjadi dalam masarakat. ${ }^{11}$ Ini tidaklah berarti bahwa masalah social kemasyarakatan tidak mengandung dimensi ibadah. Dalam Islam segala aktifitas manusia merupakan wujud peribadatan kepada Allah. ${ }^{12}$ Pembagian diatas, lebih ditunjukkan untuk memberikan terhadap masalah-masalah yang tidak menerima perubahan dan pengembangan dan masalah yang dapat menerima perubahan dan perkembangan dengan berbagai metode ijtihad dan pertimbangan yang diterapkan.

Dalam perspektif pemikiran hukum Islam (ushul al- fiqh) para ulama ushul merupakan berbagai metode dalam melakukan ijtihad hukum. Metode-metode itu, antara lain qiyas, ihstislah, istishab, dan urf..$^{13}$

Penerapan metode-metode tersebut dalam prakteknya juga didasarkan atas maqashid al-syari'ah. Maqashid al-syari'ah jamak dari kata maqsid yang berarti tuntutan, kesengajaan atau tujuan.

\section{Periode Awal Syaria'ah}

Dalam periode-periode awal, syari'ah merupakan al-nusus al-muqaddasah dari $\mathrm{Al}$ quran dan sunnah yang mutawatir yang sama sekali belum dicampuri oleh pemikiran manusia. Dalam wujud seperti ini syari'ah disebut al-tariqah al-mustaqimah. Muatan syari'ah dalam arti ini mencakup aqidah, amaliyyah dan khuhqiyah. Inilah yang dimaksud oleh firman Allah dalam Q.S. : 18 yang berbunyi

\footnotetext{
${ }^{10}$ Soerjono Soekanto, Pokok-Pokok Sosiologi Hukum, (Jakarta : Rajawali Press, 1980), h. 115.

${ }^{11}$ Halid M. Ishaque, Islamic Law: Its Ideal and Principles dalam Altaf Gauhar (Editor) The Challenge of Islam (London: Islamic Council of Europe, 1988). H. 155.

${ }^{12}$ Lihat Q.S:51:56: Dan Aku tidak menciptakan Jin dan manusia melainkan supaya mereka menyembah-KU.

${ }^{13} \mathrm{Abd}$. Al-Wahaf Khalaf, Mashadir al-Tassrik fi ma la nashsh fi, (Kuwait: dar al-Kalam, 1972), h. 67.
} 


\section{ثم جعلنا ك علي شريعة من الا مر فا تبعها}

“ Kemudian kami jadikan kamu berada di atas suatu syari'ah (peraturan) dari urusan agama itu, maka ikutilah syari'ah itu “. ${ }^{14}$

Kata syari'ah dapat diidentikkan dengan kata agama. Seperti dikatakan, maka agama dalam ayat QS. Al-Syura : 13 yang berbunyi : Dan telah mensyari'atkan bagi kamu tentang agama apa yang telah diwasiatkan-Nya kepada Nuh dan apa yang telah kami wahyukan kepadamu dan apa yang telah kami wasiatkan kepada Ibrahim, Musa dan Isa yaitu : tegakkan agama dan janganlah kamu berpecah belah tentangnya. Kata agama dalam ayat ini adalah mengesakan Allah, mentaati dan mengimani utusan-utusanNya, kitab-kitab-Nya, hari pembalasan, dan mentaati segala sesuatu yang membawa seseoran menjadi muslim.

Dalam perkembangan sekarang terjadi reduksi muatan arti syari'ah, aqidah, misalnya, tidak masuk dalam pengertian syari'at. Mahmud Syaltout, misalnya memberikan pengertian bahwa syari'ah adalah aturan-aturan yang diciptakan oleh Allah dipedomani manusia dalam mengatur hubungan dengan Tuhan, dengan manusia baik sesama muslim, alam dan seluruhnya kehidupan. ${ }^{15}$

Ali al-Sayis mengatakan bahwa syari'ah adalah hukum yang diberikan oleh Allah untuk hamba-hamba-Nya agar mereka percaya dan mengamalkannya demi kepentingan mereka di dunia dan akhirat. ${ }^{16}$

\section{Pembagian Maqashid al-Syari'ah}

Maqashid al-syari'ah dalam arti maqashid al-syari', mengandung empat aspek : keempat itu adalah :

1. Tujuan awal dari syari'ah yakni kemaslahatan manusia di dunia dan di akhirat

2. Syari'ah sebagai sesuatu yang harus dipahami

\footnotetext{
${ }^{14}$ Sejak masa Nabi Saw., maqashid al-syari'ah telah menjadi pertimbangan sebagai landasan dalam menetapkan hukum. Upaya seperti itu, seterusnya dilakukan pula oleh para sahabat. Upaya demikian terlihat secara jelas dalam beberapa ketetapan hukum yang dilakukan oleh Umar bin Khattab. Antara lain Umar tidak memberikan bagian zakat untuk kelompok non muslim, karena semula pemberian zakat kepada mereka adalah agar mereka memeluk Islam, tetapi setelah Islam kuasa dan keadaan telah berubah, maka Umar tidak memberikan bagian zakat untuk mereka

${ }^{15}$ Mahmoud Syaltout, Islamwa Syari'ah, (Kairo : Dar al-Qalam, 11), h. 12.

${ }^{16}$ Ali a-Sayis, Nashy'ah al-Fiqh al-Ijtihad wa Atwaruh, (Kairo : Majma' al-Buhus al-Islamiyyah, 1970), h.8.
} 
3. Syari'ah sebagai suatu hukum taklif yang harus dilakukan

4. Tujuan syari'ah adalah membawa manusia kebawah naungan hukum.

Aspek pertama berkaitan dengan muatan dan hakikat maqashid al-syari'ah. Aspek kedua berkaitan dengan dimensi bahasa agar syari'ah dapat dipahami sehingga dicapai kemaslahatan yang dikandungnya. Aspek ketiga berkaitan dengan pelaksanaan ketentuan syari'ah dalam rangka mewujudkan kemaslahatan. Ini juga berkaitan dengan kemampuan manusia untuk melaksanakannya. Aspek yang terakhir berkenaan dengan kepatuhan manusia sebagai mukallaf di bawah dan terhadap hukum-hukum Allah. Atau dalam istilah yang lebih tegas aspek tujuan syari'ah berupaya membebaskan manusia dari kekangan hawa nafsu.

Aspek kedua, ketiga dan keempat pada dasarnya sebagai penunjang aspek pertama sebagai aspek inti. Namun sebelum menguarikan lebih panjang aspek pertama sebagai aspek inti terlebih dahulu dipaparkan tiga aspek terakhir yang menurut al-Syatabi memiliki keterkaitan dan merupakan perincian aspek pertama.

Aspek pertama sebagai aspek inti dapat terwujud melalui pelaksanaan taklif atau pembebanan hukum terhadap para hamba sebagai aspek ketiga. Taklif tidak dapat dilakukan kecuali memiliki pemahaman baik dimensi lafal maupun maknawi sebagai aspek kedua. Pemahaman dan pelaksanaan taklif ini dapat membawa manusia berada di bawah lindungan hukum Tuhan, lepas dari kekangan hawa nafsu sebagai aspek keempat.

Dalam keterkaitan demikianlah tujuan diciptakan syari'ah yakni kemaslahatan manusia di dunia dan di akhirat sebagai aspek inti dapat diwujudkan. Dalam rangka pembagian maqashid al-syari'ah, aspek pertama sebagai aspek inti menjadi focus analisisi. Sebab, aspek pertama berkaitan dengan hakikat pemberlakuan syari'at oleh Tuhan. Hakikat atau tujuan awal pemberlakuan syari'at adalah untuk mewujudkan apabila unsure pokok dapat diwujudkan dan dipelihara. Kelima unsure pokok itu adalah agama, jiwa, keturunan, akal dan harta. ${ }^{17}$ Dalam usaha mewujudkan dan memelihara lima unsure pokok, maka terdapat tiga tingkatan maqashid atau tujuan syari'ah yaitu :

\section{Maqashid al-daruriyaat.}

2. Maqashid al-hajiyaat

\footnotetext{
${ }^{17}$ Lima unsure pokok di atas, dalam literature-literatur hukum Islam lebih di kenal dengan Ushul al-Khamsah dan susunannya adalah agama, jiwa, akal, keturunan dan harta.
} 


\section{Maqashid al-Tahsiniyat. ${ }^{18}$}

Tidak terwujudnya aspek daruriyaat dapat merusak kehidupan manusia dunia dan akhirat secara keseluruhan. Pengabaian terhadap aspek hajiyaat, tidak sampai merusak keberadaan lima unsure pokok, akan tetapi hanya membawa kepada kesulitan bagi manusia sebagai mukallaf dalam merealisasikannya. Sedangkan pengabaian aspek tahsiniyat, membawa upaya pemeliharaan lima usur pokok tidak sempurna. Sebagai contoh, dalam memelihara unsure agama, aspek daruriyaatnya antara lain mendirikan shalat. Shalat merupakan aspek daruriyaat, keharusan menghadap ke kiblat merupakan aspek hajiyaat, dan menutup aurat merupakan aspek tahsiniyat.

Apabila dianalisis lebih jauh, dalam usaha mencapai pemeliharaan lima unsure pokok secara sempurna, maka ketiga tingkat maqashid di atas tidak dapat dipisahkan. Tampaknya bahwa tingkat hajiyaat adalah penyempurnaan tingkat daruriyaat. Tingkat tahsiniyat merupakan penyempurnaan bagi tingkat hajiyaat. Sedangkan daruriyaat menjadi pokok hajiyaat dan tahsiniyat. ${ }^{19}$

Imam al- Ghazali menuliskan bahwa kebutuhan utama manusia mencakup tiga hal penting, yaitu dharury, hajy dan tahsiny. Yang prtama adalah pemenuhan kebutuhan pokok yang mencakup lima hal penting, hifdz ad-din (memelihara agama), hifdz annafs ( memelihara jiwa), hifdz al-aql ( memelihara akal ), hifdz al-mal ( memelahara harta ), hifdz al-irdl ( memelihara Kehormatan )

Eliwarti Maliki Mengelaborasi konsep tersebut srbagai bentuk penyerangan, bukan alat untuk bertahan. Secara mendalam ia menulis sebagai berikut :

a. Hifdz ad-din ( memelihara agama ) menjadi haq attadayyun ( hak Beragama ) yaitu hak untuk beribadah dan menjalankan ajaran-ajaran agama. Hak ini bukan hanya sekedar menjaga kesucian agama, namun juga membangun sarana ibadah dan menciptakan pola relasi yang sehat dalam menjalankan agama, baik antar sesama agama maupun dengan orang beda agama. Dengan demikian secara tidak langsung hak ini digunakan untuk mencipta situasi kondusif untuk mengejewantahkan keberaagamaan seseorang.

\footnotetext{
${ }^{18}$ Al-Syatibi, Al-Muwafaqat fi Ushul al-Syari'ah, (Kairo : Mustafa Muhammad, t.th), h. 8

${ }^{19}$ Ibid., h. 11 .
} 
b. Hifdz an-nafs ( menjaga jiwa ) menjadi haq alhayat ( hak hidup ). Hak ini bukan hanya sekedar sebagai alat untuk pembelaan diri,. Hak ini seharusnya diarahkan untuk mencipta kualitas kehidupan yang lebih baik bagi diri dan masyarakat. Hak hidup haris diorientasikan pada perbaikan kualitas kehidupan manusia seutuhnya, bukan secara parsial.

c. Hifdz al-aql ( memelihara akal),yaitu haq al-ta'lim ( hak mendapatkan pendidikan ) Menghargai akal bukan berarti hanya sekedar menjaga kemampuan akal untuk tidak gila ataupun mabuk. Orientasi penjagaan akal adalah pemenuhan hak intelektual bagi setiap individu yang ada dalam masyarakat. Termasuk dalam hal ini adalah terjadinya pencurian terhadap hak cipta, karya dan kreasi seseorang. Penjagaan terhadap hal tersebut adalah masuk dalam kategiri penjagaan terhadap akal, jaminan keamanan untuk karya intelektual.

d. Hifdz al-mal ( memelihara harta ), yaitu haq al-amal ( hak bekerja ). Hal ini tidak hanya diterjemahkan sebagai upaya untuk menjaga harta dari gangguan orang lain. Hak ini juga dapat diartikan sebagai hak seseorang untuk mendapatkan harta dengan cara yang halal, bekerja. Dalam arti luas, hak ini memberikan wewenang seseorang untuk membuka lapangan pekerjaan bagi orang lain. Dengan demikian, semua orang dapat mencicip hak harta dalam kehidupannya untuk mendapatkan kualitas hidup yang sejahtera.

e. Hifdz al-irdl ( memelihara kehormatan ) menjadi haq al-intirom al-insani ( hak atas kehormatan manusia ). Bukan hanya sekedar upaya untuk menjaga kehormatan diri dan keluarga dari tuduhan dan fitnah orang lain. Pelestarian adapt dan budaya adalah bagian terpenting dalam menjaga kehormatan dan martabat masyarakat. Dalam konteks yang lebih luas, menjaga martabat dan kehormatan bangsa adalah termasuk dalam pembicaraan hak menjaga kehormatan.

Uraian di atas menunjukkan bahwa penggunaan hak dlarury adalah bukan hanya sekedar upaya defensive bagi setiap individu. Lebih dari itu, ia merupakan upaya represih yang seharusnya dihadiahkan untuk meningkatkan kualitas kehidupan manusia, agama, ekonomi, social, intelektual dan budaya.

Kedua, hajy (kebutuhan sekunder) adalah kebutuhan manusia untuk mempermudah, melapangkan, menggulangi beban yang ditangguhkan dan kepayahan 
dalam kehidupan. Dalam beberapa kajian fiqh-ushul fiqh, uraian tentang ini bersifat ritual vertical. Sebagaimana uraian sebelumnya, seharusnya tafsiran ini perlu dimaknai agar lebih bersentuhan dengan kebutuhan social kemasyarakatan. Beban ekonomi, beban social, beban politik dan lain sebagainya adalah berbagai beban kehidupan yang secara rill membutuhkan kelapangan dan kemudahan dari teks keagamaan. Dengan demikian maqashid as-syari'ah tidak akan pernah kehilangan konteks dengan kehidupan rill masyarakat. Sudah selayaknya kajian ini harus diarahkan untuk penyelesaian masalah dan kasus social yang ada dalam masyarakat.

Ketiga, tahsiny (kebutuhan tersier) yaitu kebutuhan yang dituntut oleh harga diri norma dan tatanan hidup. Uraian ini terkait dengan kebutuhan keindahan tampilan diri manusia. Dalam kajian ushul fiqh, biasanya uraian ini terkait dengan pemenuhan pakaian, kendaraan dan makanan tambahan. Kajian tersebut tidak salah, namun jika dikaitkan dengan realitas kehidupan, pemaknaan sebagaimana di atas tidak membumi. Kasus kekeringan, kelaparan, penggundulan hutan, banjir, tanah longsor, global warning, dan lain lain dapat dikategorikan sebagai pemenuhan kebutuhan busung lapar dan lain sebagainya kebutuhan yang bersifat hajy.

Sebagai catatan, penulis mengutip ungkapan KH. Sahal Mahfuzd sebagai berikut: "munculnya qaul-qaul ulama terdahulu disadari sebagai sebuah hasil ijtihad mereka yang tidak lepas dari konteks social budaya yang mengitarinya. Maka dengan sedirinya pendapat tersebut tidak menjadi absolute, tidak berlaku abadi dan tidak universal. Dengan demikian menetapkan hukum atas berbagai peristiwa yang muncul saat ini berdasarkan qaul ulama terdahulu adalah merupakan pengingkaran terhadap prinsipprinsip syari'ah itu sendiri dan dengan sendirinya pula kaidah Ushul Fiqh yang mengatakan al-Islam solihun likulli izaman wal makan terkubur begitu saja.

Mashlahah sebagai tujuan syari'ah berorientasi pada pemeliharaan terhadap lima hal, yaitu memelihara agama, jiwa,akal, harta dan keturunan, tanpa terpeliharanya kelima hal tersebut, maka tidak akan tercapai mashlahah secara sempurna.

\section{Kesimpulan}

Pengkategorian yang dilakukan dalam maqashid daruriyaat, tahsiniyaat dan hajiyaat. Pada hemat penulis menunjukkan bahwa betapa pentingnya pemeliharaan lima unsure pokok itu dalam kehidupan manusia. Disamping itu pula pengkategorian itu 
mengacu tidak hanya pada pemeliharaan lima unsure, akan tetapi mengacu kepada pengembangan dan dinamika pemahaman hukum yang diciptakan oleh Tuhan dalam rangka mewujudkan kemaslahatan manusia.

Dalam rangka pemahaman dan dinamika hukum Islam, pengkategorian dalam macam maqashid tersebut dapat pula dilihat dalam dua kelompok besar yaitu dari segi keduniyaan dan keakhiratan. Pembagian maqashid ke dalam maqashid yang mengandung kemaslahatan duniawi dan ukhraw, tidak dimaksudkan untuk menarik garis pemisah secara tajam antara dua orientasi kandungan hukum Islam itu. Sebab kedua aspek itu secara hakiki tidak dapat dipisahkan dalam hukum Islam.

Pada hemat penulis, daruriyaat, hajiyaat dan tahsiniyaat, maupun pembagian pada orientasi kandungan duniawiyah dan ukhrawiyah adalah sangat penting. Kedua pembagian itu menunjukkan muatan dan skala prioritas dalam pengembangan hukum. Di samping itu dengan pembagian tersebut kita dapat menarik garis yang jelas antara lapangan (majal) hukum yang tidak boleh dilakukan ijtihad.

Jadi, dengan pemahaman maqashid al-syari'ah ijtihad dapat dikembangkan, terutama dalam menghadapi berbagai permasalahan baru yang tidak disinggung oleh nash. Dengan demikian, hukum Islam akan tetap dinamis dalam menjawab berbagai fenomena sosial yang senantiasa berubah dan berkembang. 


\section{DAFTAR PUSTAKA}

Al-Daraini, Fathi, al-Manahij al-usuliyyaah al-usuliyyaah fi Ijtihad bi al-Ra'yi fi alTasyri', Damasyik: Dar al-Kitab al-Hadits, 1975.

Al-Sayis, Ali, Nasahy'ah al-Fiqh al-Ijtihad wa Atwaruh, Kairo : Majma' al-Buhus al Islamiyyah, 1970.

Al-Syatibi, Al-Muwafaqat fi Ushul al-Syari'ah, Kairo : Mustafa Muhammad, t.th.

Al-Tiwana, Muhammad Musa, Ijtihad wa Mada Hajatina Ilaih fi Haza al-'Asr, t.t, Dar al-Kutub al-Hadisah, t.th.

Hallaq, Wael B. The Frimacy of the Qur'an in Syatibi Legal Theori. Dalam Wael B. Hallaq dan Donald P. Little (ed) Islamic Studies Presented to Charles J. Adams, Leiden : EJ-Brill, 1991.

Ishaque, Halid M., Islamic Law : Its Ideal and Principles dalam Altaf Gauhar (Editor) The Challenge of Islam London : Islamic Council of Europe, 1988.

Khallaf, Abd. Wahab, al-Wahaf, Mashadir al-Tassrik fi ma la nashsh fi, Kuwait : dar alKalam, 1972.

----------', 'Ilm Ushul al-Fiqh, Kairo : Dar Kuwatiyyah, 1968.

-----------------------, ‘ Ushul Fiqh, Kairo : Dar Kuwatiyyah, 1984

Rahman, Fazlur, Islam, akih Bahasa Ahsin Muhammad, Bandung : Pustaka, 1984.

Soekanto, Soerjono, Pokok-Pokok Sosiologi Hukum, Jakarta : Rajaawali Press, 1980.

Syaltut, Mahmoud, Islam wa Syari'ah, Kairo : Dar al-Qalam, 11.

Wehr, Hans, A Dictionary of Modern Written Arbic, J. Milton Coan, (ed), London : Macdonal and Evans LTD, 1980.

Zahrah, Muhammad Abu, Usul al-Fiqh, Mesir : Dar al-Fiqr al-'Arabi, 1958. 